\title{
Efficiency of Chemical Ripener Action in Sugarcane. VI. Growth and Qualitative Responses to Polaris as a Function of the Area of Treated Leaf Surface ${ }^{1}$
}

\begin{abstract}
Alex G. Alexander ${ }^{2}$
ABSTRACT

Growth and qualitative effects of Polaris (N,N-bis [phosphonomethyl] glycine) were examined in early-adult sugarcane in which varying proportions of the green leaf surface were treated. The blades of leaf ranks 0 to ${ }^{+} 4$ were treated individually with an aqueous Polaris solution containing $3,000 \mathrm{p} / \mathrm{m}$ active material. Treatment areas ranged from 10 to $100 \%$ of the receptive leaf canopy. Parameters for growth, juice quality, and tissue sucrose and protein components all indicated that $100 \%$ of the green leaf surface must be treated to produce maximum responses. Polaris was growth-stimulatory when applied to only $10 \%$ of the leaf surface. Significant but inconsistent qualitative responses were obtained where 10 to $60 \%$ of the leaf surface was treated. Acid invertase was the only parameter showing a significant response at the lowest treatment level and through the highest treatment level. The implications of these findings for the treatment of field cane are discussed.
\end{abstract}

\section{INTRODUCTION}

The mid-1970's saw the advent of Polaris (Monsanto Agricultural Products Co. $)^{3}$ and a few other materials having authentic potentials to increase the sucrose content of sugarcane $(2,5,6,4)$. A major challenge remained in perfecting application methods that would assure the maximum possible benefits as dictated by local varieties and their stage of maturity $(7,3)$. Chemical application by aircraft, as aqueous foliar sprays, is a convenient method but one having both logistic and economic limitations. Field-plot treatments with hand sprayers ordinarily require solution volumes in the order of 50 to 100 gallons/acre to produce maximum ripening. It is seldom feasible to apply more than about 20 gallons/acre by aircraft, and there is little control over the dispersion of sprays throughout the green foliar canopy. With closed-in canopies and where some of the cane has fallen, there is little likelihood that the ripener will penetrate more than a fraction of the receptive green-leaf surface of any given plant.

Initial ripener trials in Puerto Rico have utilized early-adult plants

\footnotetext{
${ }^{1}$ Manuscript submitted to Editorial Board April 20, 1977.

${ }^{2}$ Plant Physiologist, Agricultural Experiment Station, Mayagüez Campus, University of Puerto Rico, Río Piedras, P.R.

${ }^{3}$ Trade names are used in this publication solely for the purpose of providing specific information. Mention of a trade name does not constitute a guarantee or warranty of equipment or materials by the Agricultural Experiment Station of the University of Puerto Rico or an endorsement over other equipment or materials not mentioned.
} 
propagated by sand culture rather than field cane. Under greenhouse conditions individual plants are easily treated with a thoroughness difficult to match in the larger plants and relatively crowded plant populations of field plots. Complete wetting of the foliar canopy has been practiced so that chemical penetration per se could not be taken as a limiting factor in a candidate material's performance. It was further assumed that total coverage was in excess of material requirements for optimal effect. No information is available on the ripening contributions of individual leaf ranks, or the percentage of a plant's total leaf area that must be treated to attain the maximum ripener response. The present study was designed to clarify the area of leaf coverage required by Polaris to produce its maximum effect on growth and sugar-accumulation processes.

\section{MATERIALS AND METHODS}

Plants of the interspecific hybrid PR 980 were propagated in quartz sand as previously described (1). At 14 weeks, variable fractions of leaf ranks 0 to ${ }^{+} 4$ were treated with an aqueous Polaris solution containing $3,000 \mathrm{p} / \mathrm{m}$ active material plus $.10 \%$ Tween 20 as wetting agent. Virtually all of the fully-expanded and firmly-attached green blade area was included within these ranks. Potentially viable blade regions retained by ranks ${ }^{+} 5$ to $^{+} 7$ were not treated owing to their varying degree of desiccation and the detachment of their attending sheaths from the plant stem. The leaf treatments and approximate percentages of the total blade areas involved are presented in the following tabulation:

Treatment
No.
1
2
3
4
5
6
7

Blade rank and area treated

None (control)

$1 / 2$ of blade 0

Entire blade 0

Entire blades 0 and 1

Entire blades 0,1 , and 2

Entire blades 0, 1, 2, and 3

Entire blades $0,1,2,3$, and 4

Treated blade area
as \% of total
0
10
20
40
60
80
100

Polaris solutions were administered by hand with a two-inch paint brush. Application time was from 0700 to $0930 \mathrm{~h}$ on day 0 . There were three replications of each treatment arranged in an incomplete randomized block design.

Samples consisting of five uniform plants/replicate were harvested at $0630 \mathrm{~h}$ on day 0 and at the same hour 35 days thereafter. Green-weight measurements were taken for whole plants, tops, and millable stems. Appropriate leaf, meristem, and stalk samples were frozen for tissuecomponent analyses as described in a prior publication (1). All data were submitted to statistical analysis by the Duncan New Multiple range test. 


\section{RESULTS}

Maximum response to Polaris was attained only when $100 \%$ of the test blade area was treated. This was true for green-weight repression (table 1), juice-quality parameters (table 2), and for tissue-sucrose and protein responses (table 3). Significant growth increases were obtained when only $10 \%$ of the blade area was treated. Acid invertase was significantly repressed with as little as $10 \%$ of the blade area receiving Polaris, but maximum repression similarly required $100 \%$ coverage.

\section{DISCUSSION}

Under greenhouse conditions for cane propagation and treatment, a Polaris concentration of $3,000 \mathrm{p} / \mathrm{m}$ is about optimum for increasing sucrose without producing an excessive leaf desiccation and plant toxicity. This concentration is normally applied to the entire canopy to assure adequate penetration for the experiment at hand. For the present study, however, it was thought that a lesser leaf area, perhaps one or two thoroughly-treated blades, would suffice to produce typical Polaris responses. The present results, indicating that practically all of the viable green-leaf area must be treated for maximum response, were not anticipated. Their implication is that under field conditions the maximum ripening potential will not be realized unless very large solution volumes are applied. Somewhere in the order of 80 to 100 gallons/acre would be required to simulate the foliar coverages attained in the greenhouse. Solution quantities of this magnitude cannot realistically be applied by aircraft.

The problem of adequate chemical coverage can be solved in two ways: a) Use of ground application equipment for delivery of large solution volumes; and b) discovery of new ripeners sufficiently active to produce their maximum effect through penetration of the smaller-leaf area covered by aircraft. Ground application would appear to be necessary for maximum benefit from Polaris. Other Monsanto products have shown greater efficiency of action than Polaris $(7,3)$, and with such products the maximum benefit might possibly derive from aircraft coverage. The treatment of individual leaf ranks as herein described offers a rapid estimate of leaf-coverage requirements for candidate ripeners.

The growth-regulatory action of Polaris was shown to be a function of the quantity of ripener absorbed and translocated to a reactive site (presumably the apical meristem) rather than the material's concentration in the spray solution. While $3,000 \mathrm{p} / \mathrm{m}$ active material is growth repressive and approaches the toxic level for receptive tissues (2), 300 $\mathrm{p} / \mathrm{m}$ applied to the entire canopy is known to be growth stimulatory for Polaris (3). In the present study, $3,000 \mathrm{p} / \mathrm{m}$ applied to $10 \%$ of the receptive 
TABLE 1.-Growth responses of early-adult sugarcane following application of Polaris to varying proportions of the leaf blade surface

\begin{tabular}{|c|c|c|c|c|c|c|c|c|c|c|}
\hline \multirow{3}{*}{ Treatment } & \multirow{3}{*}{$\begin{array}{c}\text { Blade area } \\
\text { treated } \\
\text { (\% of total } \\
\text { area) }\end{array}$} & \multicolumn{9}{|c|}{ Green-wt change (g/plant), from 0 to 35 days, for - } \\
\hline & & \multicolumn{3}{|c|}{ Total green weight } & \multicolumn{3}{|c|}{ Top weight } & \multicolumn{3}{|c|}{ Stem weight } \\
\hline & & 0 & 35 & $\%$ change & 0 & 35 & $\%$ change & 0 & 35 & $\%$ change \\
\hline Control & 0 & $139 a^{2}$ & $185 \mathrm{~b}$ & $33 \mathrm{c}$ & $80 a$ & $102 \mathrm{a}$ & $28 \mathrm{bc}$ & $60 \mathrm{a}$ & $83 a b$ & $38 \mathrm{~d}$ \\
\hline Polaris ${ }^{1}$ & 10 & 123 a & 207 a & $68 \mathrm{a}$ & $72 \mathrm{a}$ & $111 \mathrm{a}$ & $54 \mathrm{a}$ & $51 \mathrm{ab}$ & 95 a & $86 \mathrm{a}$ \\
\hline Polaris & 20 & $120 \mathrm{a}$ & $178 \mathrm{bc}$ & $48 \mathrm{~b}$ & $71 \mathrm{a}$ & $100 \mathrm{ab}$ & $41 \mathrm{ab}$ & $49 \mathrm{~b}$ & $78 \mathrm{ab}$ & $59 \mathrm{~b}$ \\
\hline Polaris & 40 & 134 a & $165 \mathrm{~cd}$ & $23 \mathrm{c}$ & $80 \mathrm{a}$ & $89 \mathrm{bc}$ & $11 \mathrm{c}$ & $54 \mathrm{ab}$ & $76 \mathrm{ab}$ & $41 \mathrm{~cd}$ \\
\hline Polaris & 60 & $122 \mathrm{a}$ & $162 \mathrm{~d}$ & $33 \mathrm{c}$ & $73 \mathrm{a}$ & $85 \mathrm{c}$ & $16 \mathrm{c}$ & $49 \mathrm{~b}$ & $77 \mathrm{ab}$ & $57 \mathrm{bc}$ \\
\hline Polaris & 80 & $136 \mathrm{a}$ & $150 \mathrm{~d}$ & $10 \mathrm{~d}$ & $80 a$ & $77 \mathrm{~cd}$ & $-4 \mathrm{~d}$ & $56 \mathrm{ab}$ & $73 \mathrm{~b}$ & $30 \mathrm{~d}$ \\
\hline Polaris & 100 & $138 \mathrm{a}$ & $132 \mathrm{c}$ & $-4 c$ & $81 \mathrm{a}$ & $72 \mathrm{~d}$ & $-10 \mathrm{~d}$ & $57 \mathrm{ab}$ & $61 \mathrm{~b}$ & $7 \mathrm{c}$ \\
\hline
\end{tabular}

${ }^{1}$ Administered as an aqueous solution containing $3000 \mathrm{p} / \mathrm{m}$ active material plus $0.10 \%$ Tween 20 as wetting agent. Application time was from 0700 to $0930 \mathrm{~h}$ on day 0 . The solution was applied manually with a small paint brush.

${ }^{2}$ Mean values in the same column bearing unlike letters differ significantly $(\mathrm{P}<.05)$. 
TABLE 2.-Juice-quality responses of early-adult sugarcane following application of Polaris to varying proportions of the leaf blade surface

\begin{tabular}{|c|c|c|c|c|c|c|c|c|c|c|}
\hline \multirow{3}{*}{ Treatment } & \multirow{3}{*}{$\begin{array}{l}\text { Blade area } \\
\text { treated } \\
(\% \text { of total } \\
\text { area) }\end{array}$} & \multicolumn{9}{|c|}{ Mean values at 0 and 35 days, for - } \\
\hline & & \multicolumn{3}{|c|}{ Brix } & \multicolumn{3}{|c|}{ Polarization } & \multicolumn{3}{|c|}{ Sucrose $(\mathrm{mg} / \mathrm{ml})$} \\
\hline & & 0 & 35 & $\%$ change & 0 & 35 & $\%$ change & 0 & 35 & $\%$ change \\
\hline Control & 0 & $10.9 \mathrm{a}^{2}$ & $12.5 \mathrm{c}$ & $14.7 \mathrm{ab}$ & $30.3 \mathrm{a}$ & $38.7 \mathrm{c}$ & $27.7 \mathrm{ab}$ & $173 \mathrm{a}$ & 207 b & 19.7 c \\
\hline Polaris $^{1}$ & 10 & $11.5 \mathrm{a}$ & $12.6 \mathrm{c}$ & $9.6 \mathrm{~b}$ & $31.6 \mathrm{a}$ & $39.0 \mathrm{c}$ & $23.4 \mathrm{~b}$ & $162 \mathrm{ab}$ & $230 \mathrm{ab}$ & $42.0 \mathrm{ab}$ \\
\hline Polaris & 20 & $11.0 \mathrm{a}$ & $12.4 \mathrm{c}$ & $12.7 \mathrm{~b}$ & $30.2 \mathrm{a}$ & $37.9 c$ & $25.5 \mathrm{~b}$ & $173 \mathrm{a}$ & $214 \mathrm{~b}$ & $23.7 \mathrm{c}$ \\
\hline Polaris & 40 & $11.3 \mathrm{a}$ & $12.7 \mathrm{bc}$ & $12.4 \mathrm{~b}$ & $32.7 \mathrm{a}$ & $41.2 \mathrm{bc}$ & $26.0 \mathrm{~b}$ & $153 \mathrm{~b}$ & $225 \mathrm{ab}$ & $47.1 \mathrm{a}$ \\
\hline Polaris & 60 & $11.3 \mathrm{a}$ & $13.2 \mathrm{~b}$ & $16.8 \mathrm{ab}$ & $31.5 \mathrm{a}$ & $41.7 \mathrm{bc}$ & $29.1 \mathrm{ab}$ & $167 \mathrm{ab}$ & $215 \mathrm{~b}$ & $28.7 \mathrm{bc}$ \\
\hline Polaris & 80 & $11.3 \mathrm{a}$ & $13.3 \mathrm{~b}$ & $17.7 \mathrm{ab}$ & $30.9 \mathrm{a}$ & $44.4 \mathrm{ab}$ & $43.7 \mathrm{a}$ & $150 \mathrm{~b}$ & $226 \mathrm{ab}$ & $50.7 \mathrm{a}$ \\
\hline Polaris & 100 & $11.6 \mathrm{a}$ & $14.1 \mathrm{a}$ & $21.6 \mathrm{a}$ & $34.7 \mathrm{a}$ & $49.2 \mathrm{a}$ & $41.8 \mathrm{a}$ & $169 \mathrm{ab}$ & $261 \mathrm{a}$ & $54.4 \mathrm{a}$ \\
\hline
\end{tabular}

${ }^{1}$ Administered as an aqueous solution containing $3000 \mathrm{p} / \mathrm{m}$ active material plus $0.10 \%$ Tween 20 as wetting agent. Application time was from 0700 to $0930 \mathrm{~h}$ on day 0 . The solution was applied manually with a small paint brush.

${ }^{2}$ Mean values in the same column bearing unlike letters differ significantly $(\mathrm{P}<.05)$. 
TABLE 3.-Sucrose and protein responses in immature stem tissue following application of Polaris to varying proportions of the leafblade surface

\begin{tabular}{|c|c|c|c|c|c|c|c|c|c|c|}
\hline \multirow{3}{*}{ Treatment } & \multirow{3}{*}{$\begin{array}{l}\text { Blade area } \\
\text { treated } \\
\text { ( } \% \text { of } \\
\text { total area) }\end{array}$} & \multicolumn{9}{|c|}{ Mean values at 0 and 35 days, for - } \\
\hline & & \multicolumn{3}{|c|}{ Sucrose $(\mathrm{mg} / \mathrm{g})$} & \multicolumn{3}{|c|}{ Soluble protein (mg/g) } & \multicolumn{3}{|c|}{ Acid invertase (sp.act.) } \\
\hline & & 0 & 35 & $\%$ change & 0 & 35 & $\%$ change & 0 & 35 & $\%$ change \\
\hline Control & 0 & $98 \mathrm{ab}$ & $111 \mathrm{c}$ & $13 \mathrm{~d}$ & 65 a & $82 \mathrm{c}$ & $26 \mathrm{~d}$ & $3.9 \mathrm{a}$ & $2.6 \mathrm{a}$ & $-33 \mathrm{a}$ \\
\hline Polaris ${ }^{1}$ & 10 & $98 \mathrm{ab}$ & $122 \mathrm{bc}$ & $25 \mathrm{~cd}$ & $56 \mathrm{ab}$ & $97 \mathrm{~b}$ & $73 \mathrm{~b}$ & $4.3 \mathrm{a}$ & $2.4 \mathrm{ab}$ & $-44 b$ \\
\hline Polaris & 20 & $95 \mathrm{ab}$ & $131 \mathrm{bc}$ & $38 \mathrm{c}$ & $61 \mathrm{a}$ & $93 \mathrm{~b}$ & $53 \mathrm{c}$ & $3.9 \mathrm{a}$ & $2.0 \mathrm{bc}$ & $-49 \mathrm{~b}$ \\
\hline Polaris & 40 & $98 \mathrm{ab}$ & $123 \mathrm{bc}$ & $26 \mathrm{~cd}$ & $51 \mathrm{~b}$ & $90 \mathrm{bc}$ & $77 \mathrm{~b}$ & $4.3 \mathrm{a}$ & $2.1 \mathrm{bc}$ & $-51 \mathrm{~b}$ \\
\hline Polaris & 60 & 106 a & $139 \mathrm{~b}$ & $31 \mathrm{~cd}$ & $53 \mathrm{~b}$ & $106 \mathrm{a}$ & $100 \mathrm{a}$ & $3.8 \mathrm{a}$ & $2.0 \mathrm{bc}$ & $-47 \mathrm{~b}$ \\
\hline Polaris & 80 & $101 \mathrm{ab}$ & $195 \mathrm{a}$ & $93 \mathrm{~b}$ & $52 \mathrm{~b}$ & $60 \mathrm{~d}$ & $15 \mathrm{~d}$ & $4.1 \mathrm{a}$ & $1.7 \mathrm{c}$ & $-59 c$ \\
\hline Polaris & 100 & $89 \mathrm{~b}$ & $214 \mathrm{a}$ & $140 \mathrm{a}$ & $54 \mathrm{~b}$ & $60 \mathrm{~d}$ & $11 \mathrm{~d}$ & $4.0 \mathrm{a}$ & $1.1 \mathrm{~d}$ & $-73 d$ \\
\hline
\end{tabular}

${ }^{1}$ Administered as an aqueous solution containing $3,000 \mathrm{p} / \mathrm{m}$ active material plus $0.10 \%$ Tween 20 as wetting agent. Application time was from 0700 to $0930 \mathrm{~h}$ on day 0 . The solution was applied manually with a small paint brush.

${ }^{2}$ Mean values in the same column bearing unlike letters differ significantly $(\mathrm{P}<.05)$. 
canopy similarly produced a significant growth stimulation (table 1). Because in both instances of growth stimulation a similar quantity of Polaris was received by the plant, through vastly different areas of leaf surface, the only role of the foliar canopy appears to have been that of a collector of material. More direct contributions of leaves, i.e., a general change in photosynthetic rates, or production or transport of hormonelike materials from leaf to meristem, are not supported by the present data.

Aside from the growth stimulation noted above, statistically significant responses were sometimes produced by Polaris treatments limited to 10 to $60 \%$ of the total leaf area. Sucrose in milled juice was significantly increased by the 10 and $40 \%$ coverage treatments (table 2), and sucrose in immature storage tissue was increased by $20 \%$ coverage (table 3 ). Soluble protein in the same tissue was significantly increased by $60 \%$ coverage. These changes were relatively small and inconsistent and, in the instances of increased growth and soluble protein, are not typical of responses normally associated with chemical ripening. They are perhaps consistent with field-ripening trials where only marginal ripening is obtained with Polaris-sensitive varieties, or where no response is obtained from varieties or stages of maturation where Polaris sensitivity is much diminished.

Acid invertase was the only parameter measured showing a significant response at the lowest treatment level (10\% coverage) and a persistance of this response through the highest treatment level (table 3). This substantiates the selection of acid invertase as an important indicator of ripener activity in sugarcane. However, a complete coverage of the receptive canopy was also required to realize the chemical's maximum effect.

\section{RESUMEN}

Se examinaron los efectos de crecimiento y la eficacia madurativa de Polaris ( $\mathrm{N}, \mathrm{N}$-bis [fosfonometil] glicina en caña de azúcar adulta temprana, en la cual se trataron proporciones variables de la superficie de la hoja verde. Las láminas de las hojas de rango 0 to +4 se trataron individualmente con una solución acuosa de Polaris que contenia 3000 p.p.m. del material activo. Las áreas de tratamiento comprendieron de 10 a $100 \%$ del follaje receptivo. Todos los parámetros para crecimiento, calidad de jugo y la sacarosa del tejido y los componentes proteínicos indicaron que $100 \%$ de la superficie foliar verde debe ser tratada para producir respuestas máximas. Polaris estimuló el crecimiento cuando se aplicó a sólo el $10 \%$ de la superficie de la hoja. Se obtuvieron respuestas cualitativas significativas pero inconsistentes cuando se trató de 10 a $60 \%$ de la superficie foliar. La invertasa ácida fue el único parámetro que respondió significativamente al nivel de tratamiento más bajo y con máxima consistencıa de respuesta hasta el nivel de tratamiento máximo. Se discuten las implicaciones de estos hallazgos para el tratamiento de cańa de azúcar en el campo.

\section{LITERATURE CITED}

1. Alexander, A. G., and Montalvo-Zapata, R., 1973. Evaluation of chemical ripeners for sugarcane having constant nitrogen and water regimes. I. Growth, quality and enzymic responses to nine potential ripeners, Trop. Agric. (Trinidad), 49: 35-44.

2. Efficiency and mode of action of chemical ripeners for sugarcane, Proc. Monsanto 
Conference on Chemical Ripening of Sugarcane, Orlando, Florida, May 3-5, 1976.

3. - 1977. Efficiency of chemical ripener in sugarcane. V. Superior efficiency of CP 70139 (Monsanto) in direct comparison with Polaris, J. Agric. Univ. P.R. 61(2); 160-9.

4. Anon., More sucrose per ton of cane. Agrichemicals 3M Company release on Embark Sugarcane Ripener, 1976.

5. Nickell, L. G., and Takahashi, D. T., Field Studies with sugarcane ripeners in Hawaii, Hawaii Sugar Technol., Rep. p. 85, 1974.

6. Rostron, H., 1974. Chemical ripening with Ethrel and Polaris, Proc. Int. Soc. Sugar Cane Technol. 15: 953-5.

7. Samuels, G., and Alers-Alers, S., 1977. Evaluation of sugarcane chemical ripeners Mon 0139 and 2139 (Monsanto) in a small plot field experiment, J. Agric. Univ. P.R. 61(4): $421-8$. 